\title{
A COMPARATIVE STUDY OF QUALITY CONTROL TESTING ON CANDESARTAN CILEXETIL CONVENTIONAL TABLETS IN IRAQ
}

\section{KARRAR TALIB KHUDHAIR ALBO HAMRAH ${ }^{1}$, ABULFADHEL JABER NEAMAH AL-SHAIBANI ${ }^{1}$, SARMAD SABAH AL-EDRESI ${ }^{1}$, KARRAR MOHAMMED HASAN AL-GBURI ${ }^{2}$}

1Department of Pharmaceutics, Faculty of Pharmacy, University of Kufa, Al-Najaf, Iraq, 'Department of Clinical Pharmacy, Faculty of Pharmacy, University of Kufa, Al-Najaf, Iraq

Email: abulfadhelj.alshaibani@uokufa.edu.iq

Received: 05 Nov 2019, Revised and Accepted: 28 Feb 2020

\section{ABSTRACT}

Objective: The present study was performed to compare the quality of conventional tablets loaded with candesartan cilexetil. The selected candesartan cilexetil tablets were commercialized in the Iraq market and produced by different companies.

Methods: Different batches of candesartan cilexetil oral tablets (the concentration of candesartan was $8 \mathrm{mg}$ ) were subjected to quality control tests. Tests included weight variation, friability, hardness, drug content, disintegration time and in vitro release study. The protocols of these tests were performed according to USP pharmacopeia.

Results: The results, in this study, revealed that all the used batches of candesartan cilexetil oral tablets complied with the specification of USP pharmacopeia for weight uniformity, friability value (\% loss) was $<1$. Hardness results of the tablets were $4.9-6.6 \mathrm{Kg} / \mathrm{cm}^{2}$, which was within the required limits (i.e. $4-8 \mathrm{Kg} / \mathrm{cm}^{2}$ ). Disintegration time was $<15 \mathrm{~min}$ in both Simulated Gastric Fluid (SGF) and Simulated Intestinal Fluid (SIF). The percentage of drug content in all marketed tablets was found between $96.2 \%$ and $99.8 \%$, reflecting compliance with the pharmacopeia limits (i.e. 85-115\%). An in vitro release study indicated that the release of all marketed tablets exceeds $80 \%$ within 15 min.

Conclusion: All the studied tablets, loaded with candesartan cilexetil, were produced within the standard criteria of tablet production. The quality control analysis of the selected tablets, in this study, revealed satisfactory pharmaceutical properties (including safety and effectiveness) that comply within the limits of USP pharmacopeia.

Keywords: Quality control tests, Oral tablets, Candesartan cilexetil, Solubility

(C) 2020 The Authors. Published by Innovare Academic Sciences Pvt Ltd. This is an open-access article under the CC BY license (http://creativecommons.org/licenses/by/4.0/) DOI: http://dx.doi.org/10.22159/ijap.2020v12i2.36220. Journal homepage: https://innovareacademics.in/journals/index.php/ijap

\section{INTRODUCTION}

Quality control of drug products is an important process of the pharmaceutical industry, which is referred to as all processes that must be undertaken to ensure the purity and uniformity of marketed pharmaceuticals. Quality control study of multisource conventional pharmaceutical drug products was performed to assess the level of quality of drug products that present in the market and this assessment reflected on the patient's safety and acceptability, efficacy, potency, stability, and elegance of medications, also providing assurance to consumer that a given drug product carries out uniformly and in a satisfactory manner for the objective to which it recommended [1]. Quality control of active ingredients, excipients, and final drug products, also standards, specifications and test methods that are used in the pharmaceutical industry to ensure the quality of pharmaceuticals were regulated and provided by pharmacopeias. Efficient quality control processes assist to ensure the quality and consistency of medical products from supplier to supplier and from batch to batch [2]. Dosage forms for oral administration such as tablets and capsules have a high level of importance in the pharmaceutical markets, so quality control administrative estimates quality tests of these dosage forms for passing drug products into markets. These are orderly checked by FDA bodies [3]. Candesartan cilexetil is white to off-white crystalline powder has a molecular weight $(610.67 \mathrm{~g} / \mathrm{mol})$, possess pKa (4.23) which means it has weak acidic properties, the poor solubility and wettability of candesartan cilexetil leads to poor dissolution and hence, low bioavailability after oral administration [4]. Candesartan cilexetil available in the market as conventional oral tablets that manufactured by different companies for the treatment of many cardiovascular diseases such as hypertension, heart failure, and diabetic nephropathy, so the purpose of this study was to evaluate the quality of candesartan cilexetil conventional oral tablets that are manufactured by different pharmaceutical companies with standards of pharmacopeia and existing in Iraq pharmaceutical markets. Sunday $O$. Awofisayo conducted a study aimed at evaluating some quality control parameters to compare the quality, safety, and efficacy of nine brands of ofloxacin tablets available in the Nigerian market, the result of this study indicates that all brands complied with the official specification for uniformity of weight, friability, and disintegration. The disintegration test revealed that the drugs had higher disintegration times in simulated gastric fluid (SGF) $(7.0 \pm 0.95)$ relative to those in simulated intestinal fluid (SIF) $(5.0 \pm 2.55)$. The UVspectrophotometric assay of ofloxacin tablets revealed that three samples contained over $95 \%(\mathrm{w} / \mathrm{w})$ of labeled chemical content [5] So, the aim of this study was to compare the quality and assure safety and optimal therapeutic activity of candesartan cilexetil oral conventional tablets that were manufactured by different companies and existed in the Iraq pharmaceutical market.

\section{MATERIALS AND METHODS}

\section{Materials}

Candesartan cilexetil batches with an estimated strength of $8 \mathrm{mg}$ were purchased from a private pharmacy in Baghdad, Iraq and explained in table 1 . Candesartan cilexetil powder was supplied by Wuxi Hexia Chemical Company, China. Hydrochloric acid from Grin land chemical comp, United Kingdom. Distilled water, $\mathrm{Na}_{2} \mathrm{HPO}_{4}$, and $\mathrm{KHPO}_{4}$ were supplied by AL-ameer for chemical and laboratory materials, Baghdad, Iraq.

\section{Methods}

\section{Determination of melting point}

The melting point of candesartan cilexetil powder was measured by putting a small amount of candesartan cilexetil powdered drug into a capillary glass tube that sealed from one side and opened from another side, then the tube placed in digital melting point instrument and temperature of melting was recorded, when complete melting of powdered drug occurs [6]. 
Table 1: Marketed conventional oral tablets of candesartan cilexetil

\begin{tabular}{lll}
\hline Batch name & Manufactured company & Country \\
\hline Atacand & AstraZeneca & Sweden \\
Tenesart & Abdi Ibrahim & Turkey \\
Blopress & Arab pharm. company & Jordan \\
Candesartan & TAD & Germany \\
Diaceran & Sandoz & Germany \\
\hline
\end{tabular}

\section{Determination of the maximum wavelength of drug}

Solutions $(30 \mu \mathrm{g} / \mathrm{ml})$ of candesartan cilexetil in $\mathrm{HCl}$ buffer $(\mathrm{pH} 1.2)$ and in phosphate buffer $(\mathrm{pH}$ 6.8) were prepared, then these solutions were scanned by UV-visible spectrophotometer in the range of 200-400 $\mathrm{nm}$ [7]

\section{Calibration curves of drug in (pH 1.2) and (pH6.8)}

Stock solutions $(50 \mu \mathrm{g} / \mathrm{ml})$ of candesartan cilexetil in $\mathrm{HCl}$ buffer $\mathrm{pH}$ (1.2) and in phosphate buffer $\mathrm{pH}$ (6.8) were prepared. Then serial dilutions with different concentrations were obtained from each solution after that absorbance for each concentration was determined by using a UV-visible spectrophotometer at $200-400 \mathrm{~nm}$.

\section{Saturated solubility of candesartan cilexetil}

Candesartan cilexetil powder was added in excess amount for every $10 \mathrm{ml}$ plain tube of $\mathrm{HCl}$ buffer ( $\mathrm{pH} 1.2)$ and phosphate buffer $(\mathrm{pH}$ 6.8). Then these tubes were placed in an isothermal shaking water bath at $25 \pm 0.5^{\circ} \mathrm{C}$ for $72 \mathrm{hr}$. Then centrifugation at $2000 \mathrm{rpm}$ for 10 $\min$ and the supernatant layer for each sample filtered by using filter membrane $(0.45 \mu \mathrm{m})$. Then each sample diluted with the corresponding medium and scanned at its maximum wavelength by using a UV-visible spectrophotometer [8].

\section{Quality control tests}

\section{Weight variation test}

The test of weight variation for each batch was done by weighing 20 tablets individually using a sensitive digital balance (Kern and Sohn $\mathrm{GmbH}$. Germany). Then calculate the average weight. Then from the average weight, the determination of percent of deviation for individual tablets was made [9].

\section{Friability test}

Friability test was done by weighing 20 tablets together (initial weight), then these tablets placed in the friability tester (Erweka Friabilator tester) and adjust the instrument at $100 \mathrm{rpm}$ (25rpm for $4 \mathrm{~min}$ ) [10]. After that, the dust removed from the tablets and weighed (final weight) and friability percent obtained by the following equation:-

$$
\mathrm{F}=\frac{\text { Initial weight-Final weight }}{\text { Initial weight }} \times 100 \text { Equation } 1
$$

\section{Hardness test}

The hardness represents the strength required to crush the tablet. This test was made by using Mosanto hardness tester.

\section{Disintegration test}

The time of tablet disintegration was measured by using the disintegration test apparatus (Erweka, Germany), the apparatus consists of a basket rack containing six open-ended tubes. In each tube of the basket, one tablet was placed. The basket with the bottom surface made of a stainless steel screen (mesh no. 10) was immersed in simulated body fluids, which means simulated gastric fluid (SGF) and simulated intestinal fluid (SIF) at $37 \pm 2{ }^{\circ} \mathrm{C}$. The time at which the complete disintegration of the tablet occurs in each tube should be determined [11].

\section{Drug content assay}

Candesartan cilexetil content in the tablets of each batch was assayed by weighing 10 tablets, then these tablets crushed into fine Powder by mortar. An accurate portion of the powder equivalent to about $8 \mathrm{mg}$ of candesartan cilexetil was transferred to a $100 \mathrm{ml}$ volumetric flask containing $100 \mathrm{ml}$ of phosphate buffer ( $\mathrm{pH}$ 6.8). The flask shacked by mechanical means for one hour. Then filtration was made by using a filter membrane $(0.45 \mu)$. One $\mathrm{ml}$ from filtered solution was taken and diluted to $100 \mathrm{ml}$ with phosphate buffer $\mathrm{(pH}$ 6.8), then absorbance was measured by UV-visible spectrophotometer at maximum wavelength using phosphate buffer (pH 6.8) as blank. Tablets of each batch pass this test when the amount of drug in each tablet lies in the range of (85-115) \% of the labeled drug content [12].

\section{In vitro release study}

In vitro release study of marketed conventional oral tablets of candesartan cilexetil occurs by using dissolution apparatus USP-I (basket method). One tablet from each batch of different companies was placed in the basket and immersed in $900 \mathrm{ml}$ of phosphate buffer $\mathrm{pH}$ (6.8). The apparatus adjusts at $50 \mathrm{rpm}$ for $30 \mathrm{~min}$ at $37 \pm 0.5^{\circ} \mathrm{C}$. Five $\mathrm{ml}$ samples were withdrawn from the dissolution medium every $5 \mathrm{~min}$, after withdrawing fresh medium must be replenished to maintain sink condition. The samples filtered by using a filter membrane $(0.45 \mu \mathrm{m})$, then drug content in the samples was obtained by using a UV-visible spectrophotometer at the maximum wavelength and assay was done in triplicate [13].

\section{RESULTS AND DISCUSSION}

\section{Determination of melting point}

The determined melting point for the drug was $171{ }^{\circ} \mathrm{C}$ to $172{ }^{\circ} \mathrm{C}$. This reading represents the same reading recorded in the official sources. It gives an indication of the purity of powdered drug that utilized in the study [14]

\section{Maximum wavelength of drug}

The maximum wavelength of candesartan cilexetil in $\mathrm{HCl}$ buffer (pH1.2) and in phosphate buffer (pH 6.8) appears at $254 \mathrm{~nm}$ [15], as shown in fig. 1 and 2 that explain the UV spectra of the drug, $\mathrm{HCl}$ buffer (pH 1.2) and phosphate buffer ( $\mathrm{pH}$ 6.8) respectively.

\section{Calibration curves of drug in (pH 1.2) and (pH6.8)}

Calibration curves of candesartan cilexetil in $\mathrm{HCl}$ buffer (pH1.2) and in phosphate buffer (pH 6.8) were determined by plotting the absorbencies against concentrations. A straight line with a high value of the regression coefficient was obtained. This indicates the curve agreement with BeerLambert's law at $\lambda$ max $254 \mathrm{~nm}$ with concentrations that are used. The fig. 3 and 4 explain the calibration curves of the drug in $\mathrm{HCl}$ buffer (pH1.2) and in phosphate buffer ( $\mathrm{pH} 6.8$ ) respectively.

\section{Saturated solubility of candesartan cilexetil}

Candesartan cilexetil saturated solubility in dissolution media indicates that drug has highest solubility in phosphate buffer $\mathrm{(pH}$ 6.8) which is $(0.063 \mathrm{mg} / \mathrm{ml})$, while the solubility of drug in $\mathrm{HCl}$ buffer ( $\mathrm{pH} 1.2)$ was $(0.007 \mathrm{mg} / \mathrm{ml})$, this gives an indication that the drug has weak acidic properties and highest solubility is obtained in basic medium [16].

\section{Quality control tests}

\section{Weight variation test}

According to USP, the accepted percent of weight variation of tablet (over $130 \mathrm{mg}$ ) is $( \pm 7.5$ ) as noted in marketed products (Atacand, Tenesart, Blopress, and Candesartan TAD) and for tablet, less than $130 \mathrm{mg}$ is $( \pm 10)$ as noted in product (Diaceran) [17], so the results of weight variation of all marketed products from different companies within the acceptance limit as shown in table 2 and fig. 5 explains the lowest and highest percentage of weight variation. 


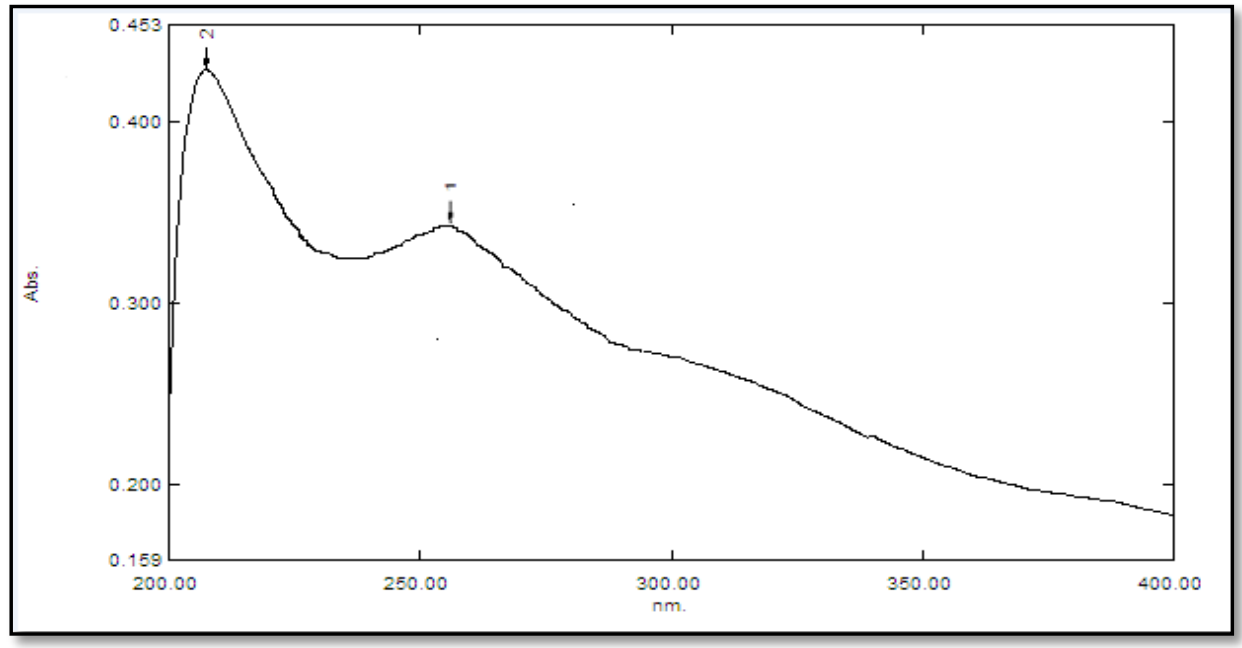

Fig. 1: UV spectrum of the drug in $\mathrm{HCl}$ buffer (pH1.2) at $254 \mathrm{~nm}$

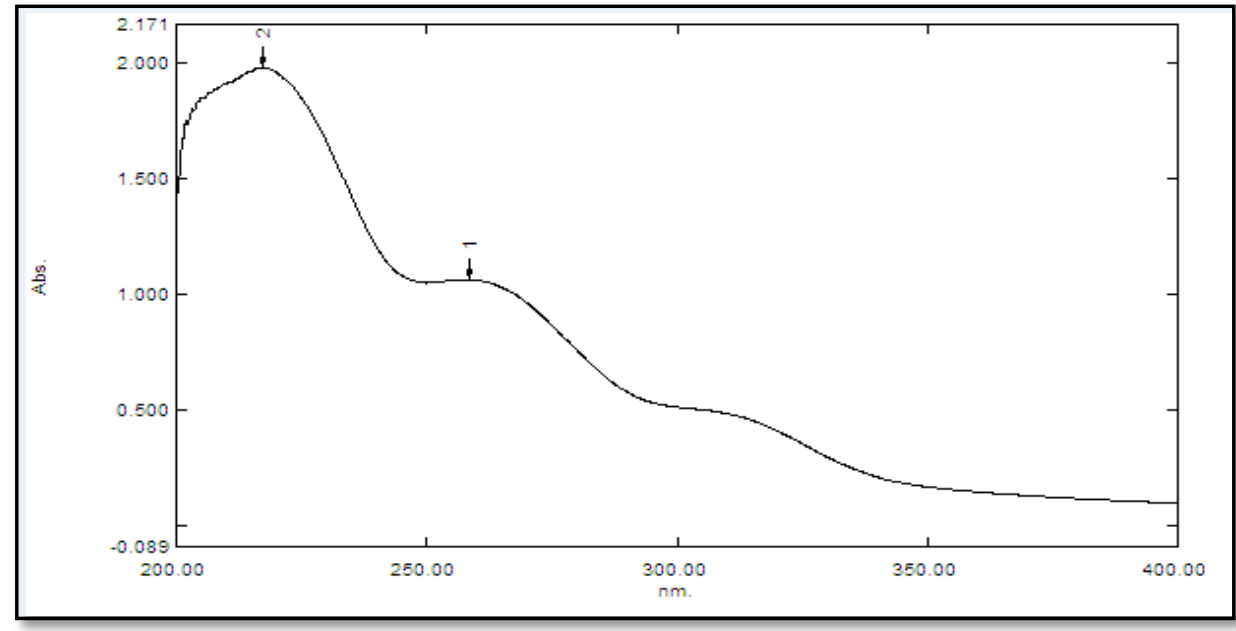

Fig. 2: UV spectrum of the drug in phosphate buffer (pH 6.8) at $254 \mathrm{~nm}$

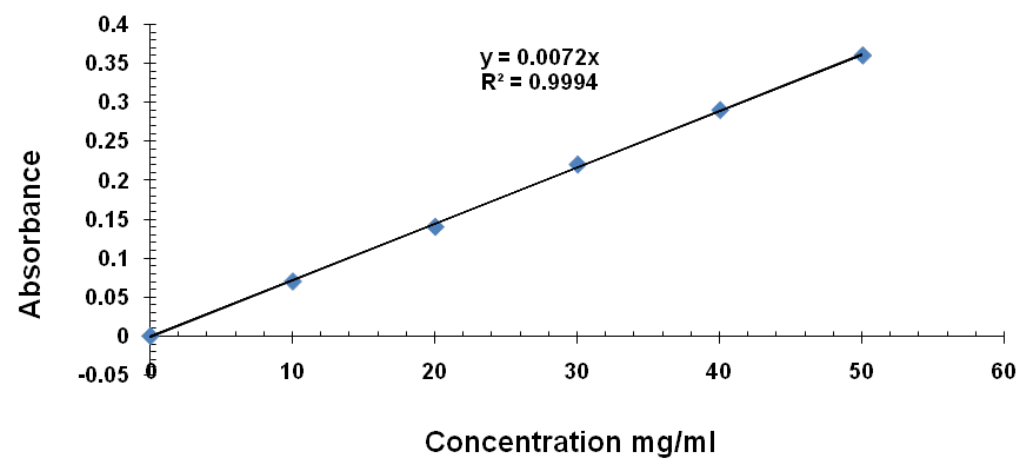

Fig. 3: Calibration curve of the drug in $\mathrm{HCl}$ buffer (pH1.2)

Table 2: Weight variation of marketed products of candesartan cilexetil (mean $\pm S D, n=3$ )

\begin{tabular}{lllll}
\hline Batch name & Weight of tablet individually (mg) & Average weight of (20) tablets (mg) & Percent of weight variation & Lowest percent \\
\hline BN & Lowest weight & Highest weight & Average weight (mg) & $0.763 \pm 0.20$ \\
\hline Atacand & $130 \pm 0.90$ & $133 \pm 0.12$ & $131 \pm 0.21$ & $1.526 \pm 0.10$ \\
Tenesart & $130 \pm 0.11$ & $135 \pm 0.14$ & $132 \pm 0.53$ & $2.272 \pm 0.10$ \\
Blopress & $132 \pm 0.13$ & $137 \pm 0.11$ & $134 \pm 0.51$ & $2.238 \pm 0.30$ \\
Candesartan & $130 \pm 0.11$ & $137 \pm 0.10$ & $132 \pm 0.19$ & $1.492 \pm 0.10$ \\
Diaceran & $98.4 \pm 0.16$ & $100.5 \pm 0.21$ & $99.1 \pm 0.33$ & $1.515 \pm 0.10$ \\
\hline
\end{tabular}




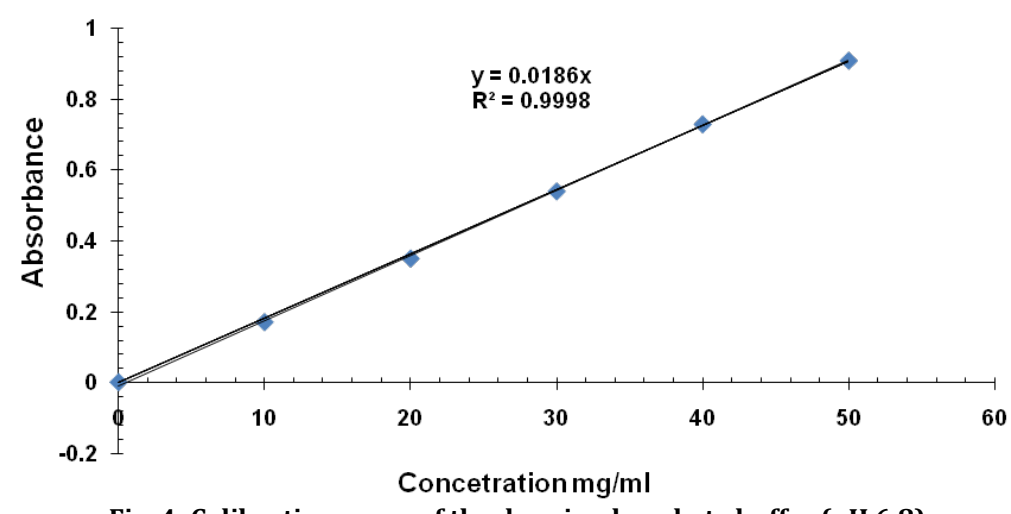

Fig. 4: Calibration curve of the drug in phosphate buffer (pH 6.8)

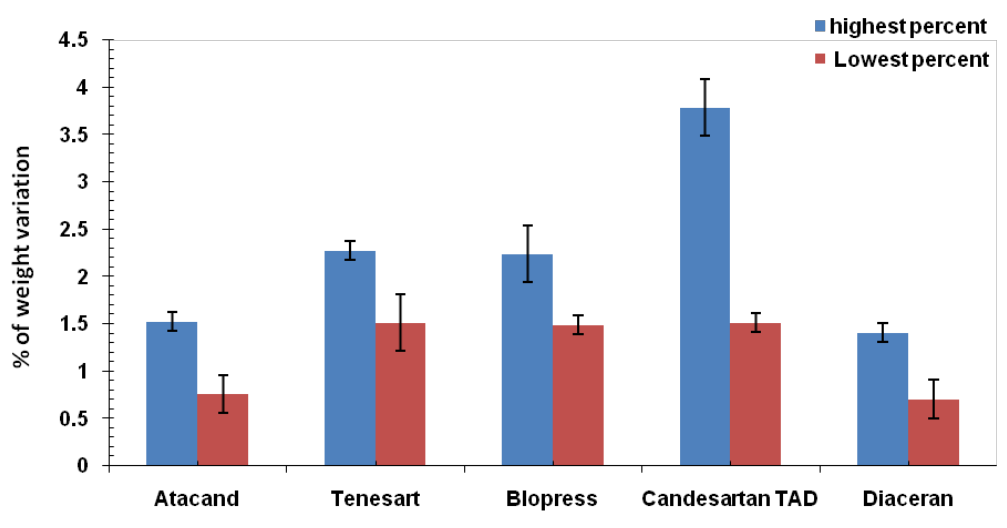

Candesartan cilexetil tablets

Fig. 5: Percent of weight variation of marketed products (mean $\pm S D, n=3$ )

Table 3: Friability values of marketed products of candesartan cilexetil (mean $\pm S D, n=3$ )

\begin{tabular}{|c|c|c|c|c|}
\hline Batch name & Number of tablets & Weight before the test (gm) & Weight after the test (gm) & Friability (\% loss) \\
\hline Atacand & 20 & $2.62 \pm 0.11$ & $2.61 \pm 0.21$ & $0.38 \pm 0.11$ \\
\hline Tenesart & 20 & $2.64 \pm 0.36$ & $2.62 \pm 0.31$ & $0.76 \pm 0.23$ \\
\hline Blopress & 20 & $2.68 \pm 0.34$ & $2.67 \pm 0.12$ & $0.37 \pm 0.21$ \\
\hline Candesartan & 20 & $2.64 \pm 0.65$ & $2.63 \pm 0.17$ & $0.38 \pm 0.17$ \\
\hline Diaceran & 20 & $1.98 \pm 0.45$ & $1.97 \pm 0.11$ & $0.50 \pm 0.13$ \\
\hline
\end{tabular}

\section{Friability test}

The value of friability ( $\%$ loss) is less than or equal to $1 \%$, the batch is accepted [18], table 3 explains the results of friability (\%loss), which are less than one (0.37-0.76), this gives an indication that all marketed products of drug within the accepted limit of USP pharmacopeia.

\section{Hardness test}

The hardness of tablets was measured to see the ability of the tablet to withstand mechanical shocks of handling in manufacture, packaging, and breakage during transportation. Recently, the relationship of hardness to tablet disintegration and the drug dissolution (release) rate has become apparent. According to USP, the crushing strength of (4-8 Kg) for uncoated tablets is acceptable [19], hence the results of the hardness test of all marketed tablets that were used in the study within the acceptable limit as shown in table 4.

\section{Disintegration time}

Disintegration time was regarded as a very important test in quality control of conventional immediate-release tablet especially that was used for the treatment of chronic diseases and required rapid onset of action such as hypertension and heart failure. According to USP, maximum disintegration time of uncoated tablet is (30 $\mathrm{min})$ [20], all marketed tablets that were used in the study have good disintegration time (less than $15 \mathrm{~min}$ ) in both SGF and SIF, as shown in table 4.

\section{Drug content}

The content of the candesartan cilexetil of the marketed conventional oral tablets complies with USP limitations. The percent of drug content in all marketed products was found in the range of (96.2-99.8\%), indicating the compliance with the pharmacopeia limits. No tablet lies out of the range of $(85-115 \%)$ of the label claim. These results indicate that uniform distribution and an excellent quantity of active ingredients were found in the marketed tablets of different companies [21]. The results of drug content explained in table 4.

\section{In vitro release study}

The bioavailability of the drug of oral conventional tablets depends completely on the dissolution rate of the drug. So, it is very important to estimate the dissolution rate and compare the dissolution profiles of different marketed products. According to USP, the dissolution rate for oral conventional tablets should be at least $80 \%$ within one hour. The results of in vitro release study give 
an indication that all marketed products of candesartan cilexetil of different companies meet USP specification, that means the release exceeds $80 \%$ within $15 \mathrm{~min}$, the fig. 6 explain that blopress products released maximum amount of candesartan cilexetil (97.55\%), while the diaceran product released minimum amount of drug among different products $(89.77 \%)$.

Table 4: Hardness, disintegration time and drug content of marketed products, where hardness and disintegration time (mean \pm SD, $n=3$ )

\begin{tabular}{|c|c|c|c|c|}
\hline Batch name & Hardness $\left(\mathrm{Kg} / \mathrm{cm}^{2}\right)$ & Disintegration time (min) in SGF & Disintegration time (min) in SIF & Drug content (\%) \\
\hline Atacand & $5.10 \pm 0.56$ & $9.41 \pm 0.20$ & $11.12 \pm 0.60$ & 99.30 \\
\hline Tenesart & $6.60 \pm 0.73$ & $14.30 \pm 0.91$ & $14.46 \pm 1.03$ & 96.20 \\
\hline Blopress & $4.90 \pm 011$ & $7.57 \pm 0.32$ & $8.37 \pm 0.54$ & 99.80 \\
\hline Candesartan & $5.70 \pm 0.42$ & $8.55 \pm 0.04$ & $10.05 \pm 0.89$ & 98.20 \\
\hline Diaceran & $6.10 \pm 0.13$ & $11.02 \pm 0.61$ & $14.56 \pm 1.12$ & 98.90 \\
\hline
\end{tabular}

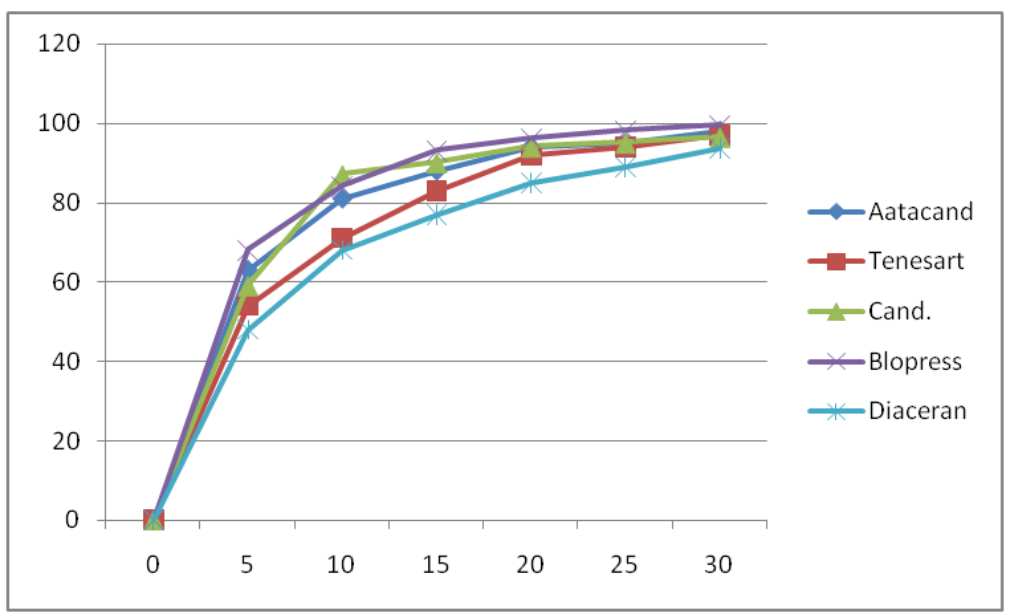

Fig. 6: In vitro release profile of marketed oral conventional tablets of candesartan cilexetil in dissolution medium (pH 6.8)

\section{CONCLUSION}

In this research, it has been concluded that the properties of all batches of candesartan cilexetil oral tablets were in agreement with the specifications of the USP Pharmacopeia. The studied properties were weight variation, friability, hardness, disintegration time and release of the drug. Drug content was $96.2-99.8 \%$ and the release was $80 \%$ in $15 \mathrm{~min}$. The analysis of the selected tablets in this study revealed that the tablets were manufactured in a satisfactory manner for the objectives to which is recommended.

\section{ACKNOWLEDGMENT}

Authors give thanks and gratitude for the department of pharmaceutics, faculty of pharmacy, the University of Kufa on everything they have done for the completion of this research.

\section{FUNDING}

Nil

\section{AUTHORS CONTRIBUTIONS}

All the authors have contributed equally.

\section{CONFLICT OF INTERESTS}

Declared none

\section{REFERENCES}

1. Syed Masudur Rahman Dewan, Ashraful Alam. A comparative quality control study on conventional ibuprofen tablets available in banglaeshi pharma market. Int Res J Pharm 2013:4:96-8.

2. Hendriksen C, Arciniega JL, Bruckner L, Chevalier M, Coppens E. The consistency approach for the quality control of vaccines. Biologicals 2008;36:73.

3. Shabana Md. A review on the quality control analysis of oral dosage form: tablets. Res Rev: J Pharm Pharm Sci 2016;5:108-14
4. Al-Nuss Raghad, El-Zein Hind. Enhancement of the candesartan cilexetil dissolution rate by using different methods. Asian J Pharm Clin Res 2015;8:320-6.

5. Sunday O Awofisayo, Oladoja A Awofisayo. Comparative assessment of the quality control measurements of multisource ofloxacin tablets marketed in nigeria. Dissolution Technol 2010;6:20-5.

6. Bandyopadhyay S, Bhuria L, Lal D. An explicit review on quantitative estimation of candesartan cilexetil employing various analytical techniques. Pharma Anal Acta 2013;4:1-7.

7. Sandeep Lahoti, Sanjay Toshniwal. Development and validation of UV. Spectrophotometric method of nimodipine in bulk and tablet formulation. Asian J Biomed Pharm Sci 2012;2:8-10.

8. Mowafaq M Ghareeb, Abulfadhel J Neamah. Formulation and characterization of nimodipine nanoemulsion as ampoule for oral route. Int J Pharm Sci Res 2017;8:591-2.

9. Gupta MM, Gupta M. Comparative pharmaceutical quality control testing of different brands of paracetamol tablets available in the trinidad and tobago, West Indies. Int J Pharm Sci Res 2016;7:2830-6.

10. Ramakrishna S, Mihira V, Raja Vyshnavi K, Ranjith V. Design and evaluation of drug release kinetics of meloxicam sustained release matrix tablets. Int J Curr Pharm Res 2012;4:90-9.

11. Mazhar Rasool Shah, Muhammad Iqbal Nasiri, Sohail Anwer Pharmaceutical quality assessment of different brands of moxifloxacin $400 \mathrm{mg}$ tablets available in Pakistan. RADS J Pharm Pharm Sci 2019;7:2-8.

12. Shailaja T, Latha K, Alkabab AM. Formulation and evaluation of orodispersible tablets of metoprolol tartrate with natural and synthetic superdisintegrants. Int J Pharm Pharm Sci 2012;4:148-54.

13. Avinash Mahatme, Vijay R Mahajan, VR Gudsoorkar. Formulation and evaluation of immediate-release tablet of amlodipine. Literati J Pharm Drug Delivery Technol 2015;3:26-9.

14. Abulfadhel Jaber Neamah AL-Shaibani, Karrar Mohammed Hasan Al-Gburi, Karrar Talib Khudhair Albo Hamrah. Design and characterization of candesartan cilexetil oral 
nanoemulsion containing garlic oil. Int J Appl Pharm 2019; 6:116-24.

15. Shaimaa Nazar Abd Alhammid. Enhancement of the solubility and the dissolution rate of candesartan cilexetil using microsponge technology. Asian J Pharm Clin Res 2018;9:385-90.

16. GN Darwhekar, DK Jain, Jitendra Chouhan. Biopharmaceutical classification of candesartan and candesartan cilexetil. Asian J Pharm Life Sci 2012;2:295-302.

17. The United State Pharmacopeia. USP30-NF25. Convention Inc Rockville MD. General tests and assays CD; 2007.
18. US Pharmacopoeia. United States Pharmacopoeial Convention, Thirty-Seventh Edition; 2014. p. 342-51, 1571-72.108

19. Parrot EL, Saski W. Solid pharmaceuticals. In: Experimental pharmaceutical technology. $3^{\text {rd }}$ ed. Burgess Publishing Co.: Minneapolis MN; 1971. p. 58-106.

20. Gupta MM, Patel Vishal. Formulation and evaluation of oral dispersible tablet of cinnarizine. I Drug Delivery Ther 2013;3:12-7.

21. Naik Prajakta Satish, Kurup Nalini Satish. Design and optimization of fast dissolving tablets containing metoprolol by sublimation method. Int Res J Pharm 2010;1:346-57. 